\title{
Screening and identification of resistance related proteins from apple leaves inoculated with Marssonina coronaria (Ell. \& J. J. Davis)
}

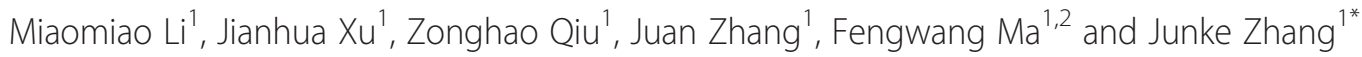

\begin{abstract}
Background: Apple, an invaluable fruit crop worldwide, is often prone to infection by pathogenic fungi. Identification of potentially resistance-conferring apple proteins is one of the most important aims for studying apple resistance mechanisms and promoting the development of disease-resistant apple strains. In order to find proteins which promote resistance to Marssonina coronaria, a deadly pathogen which has been related to premature apple maturation, proteomes from apple leaves inoculated with M. coronaria were characterized at 3 and 6 days post-inoculation by two dimensional electrophoresis (2-DE).
\end{abstract}

Results: Overall, 59 differentially accumulated protein spots between inoculation and non-inoculation were successfully identified and aligned as 35 different proteins or protein families which involved in photosynthesis, amino acid metabolism, transport, energy metabolism, carbohydrate metabolism, binding, antioxidant, defense and stress. Quantitative real-time PCR (qRT-PCR) was also used to examine the change of some defense and stress related genes abundance under inoculated conditions.

Conclusions: In a conclusion, different proteins in response to Marssonina coronaria were identified by proteomic analysis. Among of these proteins, there are some PR proteins, for example class III endo-chitinase, beta-1,3-glucanase and thaumatine-like protein, and some antioxidant related proteins including aldo/keto reductase AKR, ascorbate peroxidase and phi class glutathione S-transferase protein that were associated with disease resistance. The transcription levels of class III endo-chitinase (L13) and beta-1, 3-glucanase (L17) have a good relation with the abundance of the encoded protein's accumulation, however, the mRNA abundance of thaumatine-like protein (L22) and ascorbate peroxidase (L28) are not correlated with their protein abundance of encoded protein. To elucidate the resistant mechanism, the data in the present study will promote us to investigate further the expression regulation of these target proteins.

Keywords: Apple, 2-DE, Comparative proteomics, M. coronaria, Quantitative real-time PCR

\section{Background}

The common apple (Malus domestica) has not only become one of the world's largest fruit crops, but has also served as an invaluable model organism for the study of commercial traits such as disease and pest resistance [1]. Marssonina apple blotch caused by the fungus Diplocarpon mali is a devastating defoliating disease which can infect apple tree leaves, twigs, and fruit during the growing season [2,3]. Infection usually occurs during periods of

\footnotetext{
* Correspondence: zhangjk@nwsuaf.edu.cn

'College of Horticulture, Northwest A \& F University, Yangling, Shaanxi

712100, China
}

Full list of author information is available at the end of the article warm, damp weather conditions. Ascospores released from overwintered apothecia on leaves are considered the inoculum for primary infections, and conidia produced in acervuli are thought to be responsible for secondary infections during the apple growing season. This disease is first manifested by brown spots and dark green circular patches on the leaf upper surfaces in mid-Summer. As it progresses, those spots coalesce with each other and black pinhead-like asexual fruiting bodies develop on the affected tissue [4]. Severe infections often lead to premature defoliation, which weakens tree vigor and diminishes crop yield and quality. Infections usually occur in consecutive

\section{Biomed Central}

(c) 2014 Li et al.; licensee BioMed Central Ltd. This is an open access article distributed under the terms of the Creative Commons Attribution License (http://creativecommons.org/licenses/by/2.0), which permits unrestricted use, distribution, and reproduction in any medium, provided the original work is properly cited. 
years and have become a serious problem at several apple production areas in China [5].

To solve this problem, a better understanding of the complex plant defense mechanisms against Marssonina coronaria infection is extremely important. The optimum conditions for Marssonina coronaria growth researched by Dong-Hyuk Lee which supply the method of bacteria culture in vitro for us [6]. Hua Zhao et al obtained the mode of Marssonina coronaria infection and infection progress using fluorescence and electron microscopy [7]. Lihua Yin et al reported that 'Qinguan' had signs of disease resistance, with a low incidence of Marssonina coronaria infection [8]. Q. Zhou et al described the characterization of defense-related genes in the 'Qinguan' apple in response to Marssonina coronaria by cDNA suppression subtractive hybridization analysis [9]. However, these studies were limited to epidemiology and gene level, not touch upon the level of protein.

The proteins are the final executors of most biological processes. Proteome analysis, which focuses on investigating accumulative changes and modifications of proteins, could lead to a more comprehensive understanding of biotic stresses in host plants [10]. Two-dimensional (2-D) gel electrophoresis has emerged as a powerful tool for the study of plant-stress responses to plant-herbivore and plant-pathogen interactions [11-13]. It has been successfully applied to analysis of proteomics in different plant [14-16]. Despite the promising results of these and other studies, no investigation has been made into the identification of potential disease resistance-related proteins in the Marssonina apple blotch.

This study seeks to obtain potentially resistant proteins, from the detached leaves from 'Qinguan' apples and analyze the proteome via two-dimensional (2-D) gel electrophoresis. Data from this study could be used to facilitate the development of plans resistant to the Marssonina apple blotch.

\section{Results}

\section{Pathogenesis of $M$. coronaria on isolated apple leaves}

Individual leaf symptoms of infection following inoculation with $M$. coronaria were observed and recorded. No visible symptoms including color or structure change had occurred at 3 day after inoculation compared to control. However, some small black lesions were observed at 6 day post inoculation, indicating successful inoculation and sufficient infection. Morphological changes observed during the infection are presented in Figure 1.

\section{Identification of Marssonina coronaria-responsive proteins by $2-\mathrm{DE}$ and $\mathrm{MS}$}

In order to verify the change of different resistancerelated proteins abundance between inoculated and non inoculated conditions, proteomic profiles of apple leaves were obtained via 2-D gel electrophoresis. A total of eighty-one protein spots showed significantly differential

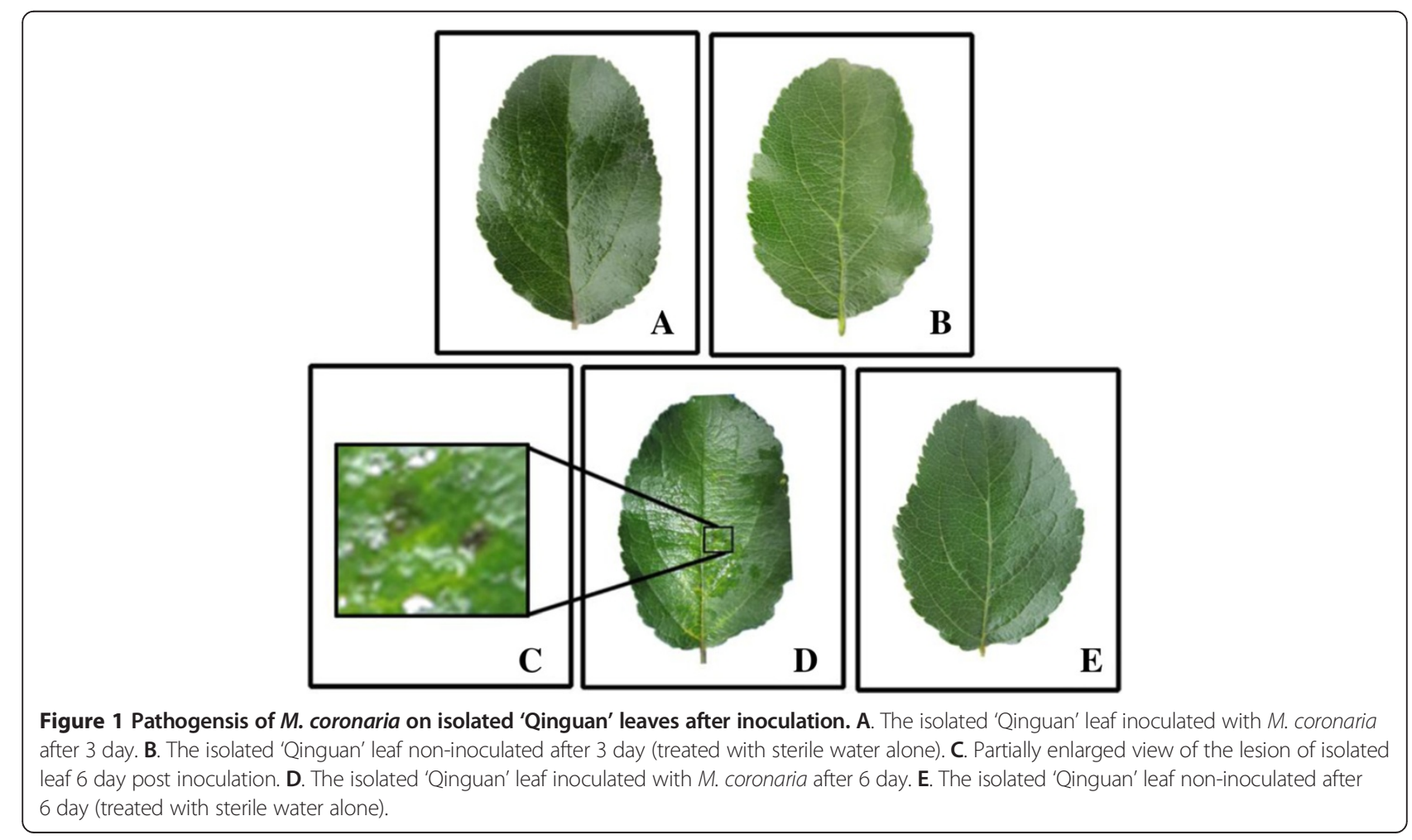


change in abundance between inoculated and control groups, see Figure 2. These spots were excised from the gel, and fifty-nine protein spots were identified successfully by peptide digestion followed by TOF/MS and proteomic peptide library identification via BLAST search and the results were listed out in Table 1. According the protein function, these proteins were aligned into thirty-five proteins or protein family.

\section{Functional classification and subcellular localization of pathogenically induced proteins}

The fifty-nine successfully identified protein spots were grouped according to the biological process using the GO annotation in the Green Plant database (http://www. geneontology.org/). The identified proteins fall into 9 functional categories including photosynthesis (twelve spots, 19\%), amino acid metabolism (3 spots, $5 \%$ ), transport (4 spots, 7\%), energy metabolism (2 spots, 3\%), carbohydrate metabolism (twelve spots, $20 \%$ ), binding (8 spots, $14 \%$ ), antioxidant (2 spots, $3 \%$ ), defense and stress (eleven spots, 19\%) and unknown (5 spots, $8 \%$ ). The most important categories related to infectivity included defense and stress related proteins, accounting for 19\% of the total, and antioxidant related proteins which accounted for 3\% (Table 1, Figure 3).

Subcellular location analysis provides important information about the physiological function of identified proteins [17]. The GO annotations have been widely used to predict the locations of proteins because the two are strongly correlated $[18,19]$. Some of the identified proteins (L8, L50, L51, L82, L85, L95, L58, L27, L83, L68, L69, L71, L72, L73, L77, L78, L79, L56, L99, L23 and L59) were localized to chloroplasts, and others to stroma (L45, L49), thylakoid membrane (L15, L19, L61 and L87), cytosol (L36, L41), and the cell wall (L89). Localization of all other proteins could not be determined (Figure 4).

\section{Protein abundance change in response to $M$. coronaria inoculation in apple leaves}

After inoculation, fifty-nine protein spots were identified successfully, classified into 3 groups: proteins that showed increased in protein abundance only at 3 day after M. coronaria inoculation compared to the control (Group A); proteins that showed increased in protein abundance versus control at 6 day timepoint in response
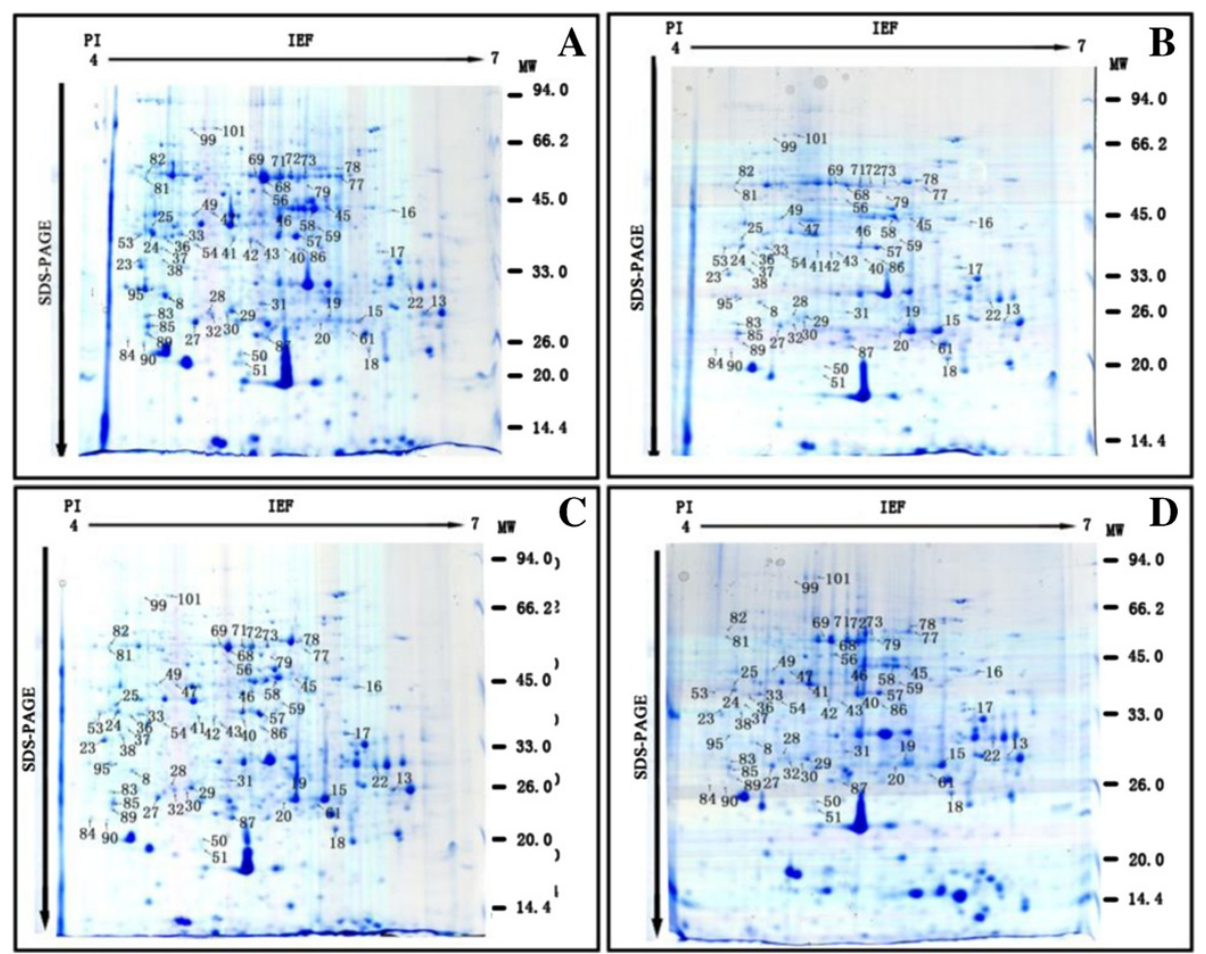

Figure 2 Annotated gel images of 'Qinguan' leaf proteome. 2-DE protein profiles of non-inoculated (B, D) and inoculated (A, C) leaves of 'Qinguan' in response to Marssonina coronaria infection. Significantly altered and identified spots are marked with corresponding spot number. The name of the protein is shown in Table 1. For the first dimension, $1000 \mu \mathrm{g}$ of proteins were loaded on a $17 \mathrm{~cm}$ IPG strip with a linear gradient of $\mathrm{pH}$ 4-7, and 12\% SDS-PAGE gels were used for the second dimension. The gels were stained by colloidal Coomassie brilliant blue G-250. M. molecular marker. A. Inoculated with Marssonina coronaria after 3 day. B Non-inoculated after 3 day (treated with sterile water alone). C. Inoculated with Marssonina coronaria after 6 day. D. Non-inoculated after 6 day (treated with sterile water alone). 
Table 1 Proteins identified and analyzed by MALDI-TOF-TOF/MS

\begin{tabular}{|c|c|c|c|c|c|c|c|}
\hline Spot no & Protein name & Accession no. & $\begin{array}{c}\text { Deduced apple } \\
\text { genome ID }\end{array}$ & $\begin{array}{l}\text { Protein } \\
M W / P I\end{array}$ & $\begin{array}{l}\text { Pep. } \\
\text { count }\end{array}$ & $\begin{array}{l}\text { Protein } \\
\text { score }\end{array}$ & $\begin{array}{l}\text { Relative protein } \\
\text { content }\end{array}$ \\
\hline \multicolumn{8}{|c|}{ Photosynthesis proteins } \\
\hline L8 & ribulose-1,5-bisphosphate carboxylase & gi|2961315 & MDP0000597996 & $53314.4 / 6.14$ & 5 & 253 & \begin{tabular}{l|}
- \\
- \\
-
\end{tabular} \\
\hline$\llcorner 45$ & $\begin{array}{c}\text { ribulose-1,5-bisphosphate carboxylase/oxygenase } \\
\text { activase alpha } 2\end{array}$ & gi|78100212 & MDP0000944409 & $46944.1 / 4.84$ & 12 & 494 & $\begin{array}{l}- \\
- \\
- \\
- \\
- \\
-\end{array}$ \\
\hline$\llcorner 49$ & $\begin{array}{c}\text { ribulose-1,5-bisphosphate carboxylase/oxygenase } \\
\text { activase small protein isoform }\end{array}$ & gi|115334979 & MDP0000321244 & $47952.1 / 7.57$ & 10 & 326 & $\begin{array}{l}- \\
- \\
-\end{array}$ \\
\hline L50 & $\begin{array}{l}\text { Oxygen-evolving enhancer protein 2, chloroplastic; } \\
\text { Short = OEE2; }\end{array}$ & gi|11134051 & MDP0000361338 & $28674.3 / 6.6$ & 4 & 231 & $\begin{array}{l}- \\
- \\
- \\
- \\
-\end{array}$ \\
\hline L51 & ribulose 1,5-bisphosphate carboxylase & gi|4206530 & MDP0000597996 & $49888.8 / 5.94$ & 3 & 223 & - \\
\hline L82 & ribulose 1,5-bisphosphate carboxylase & gi|10945633 & MDP0000597996 & $52133 / 6.18$ & 8 & 154 & $\begin{array}{l}- \\
- \\
- \\
-\end{array}$ \\
\hline L85 & ribulose-phosphate 4-epimerase & gi|225457361 & MDP0000137234 & $30146 / 8.93$ & 5 & 533 & $\begin{array}{l}\overline{-} \\
\overline{-} \\
\overline{-}\end{array}$ \\
\hline L95 & ribulose 1,5-bisphosphate carboxylase & gi|371928199 & MDP0000597996 & $49673 / 6.04$ & 20 & 498 & $\begin{array}{l}- \\
- \\
- \\
- \\
-\end{array}$ \\
\hline L15 & Chlorophyll $a-b$ binding protein 3C-like protein & gi|357497757 & MDP0000784451 & $24884.4 / 5.53$ & 4 & 133 & - ${ }^{-}$- 再 䙳 \\
\hline L19 & putative chlorophyll a/b binding protein & gi|397789264 & MDP0000875642 & $16135 / 7.82$ & 6 & 262 & $\begin{array}{l}- \\
- \\
- \\
-\end{array}$ \\
\hline L61 & Chlorophyll a-b binding protein 2, chloroplastic; & gi|158562858 & MDP0000708928 & $3798.9 / 8.2$ & 4 & 212 & $-\overline{-}$ \\
\hline L87 & chlorophyll a-b binding protein 8, chloroplastic & gi|225436257 & MDP0000866655 & $29511.2 / 7.85$ & 2 & 192 & 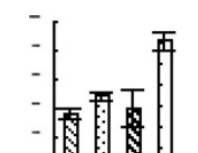 \\
\hline
\end{tabular}




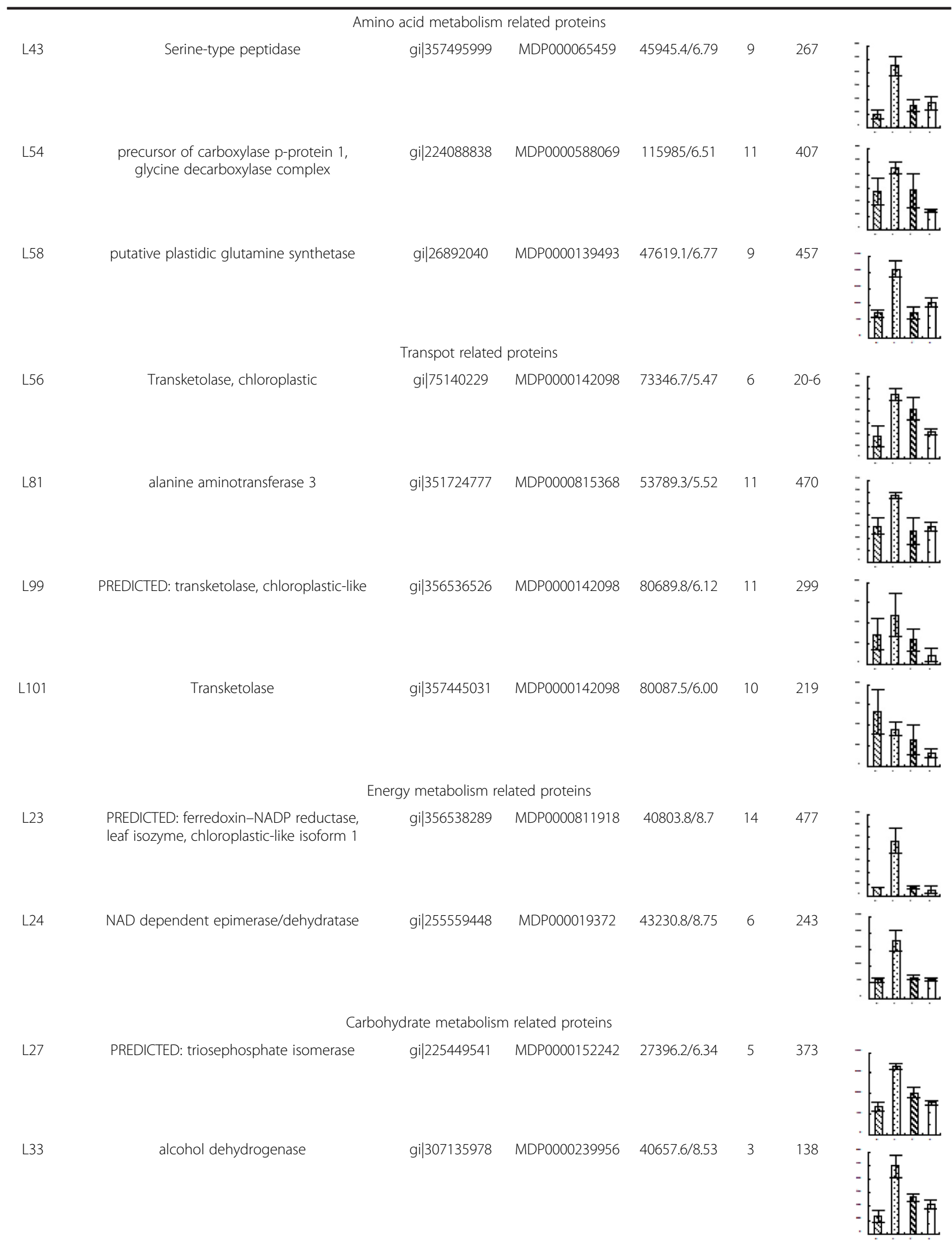


Table 1 Proteins identified and analyzed by MALDI-TOF-TOF/MS (Continued)

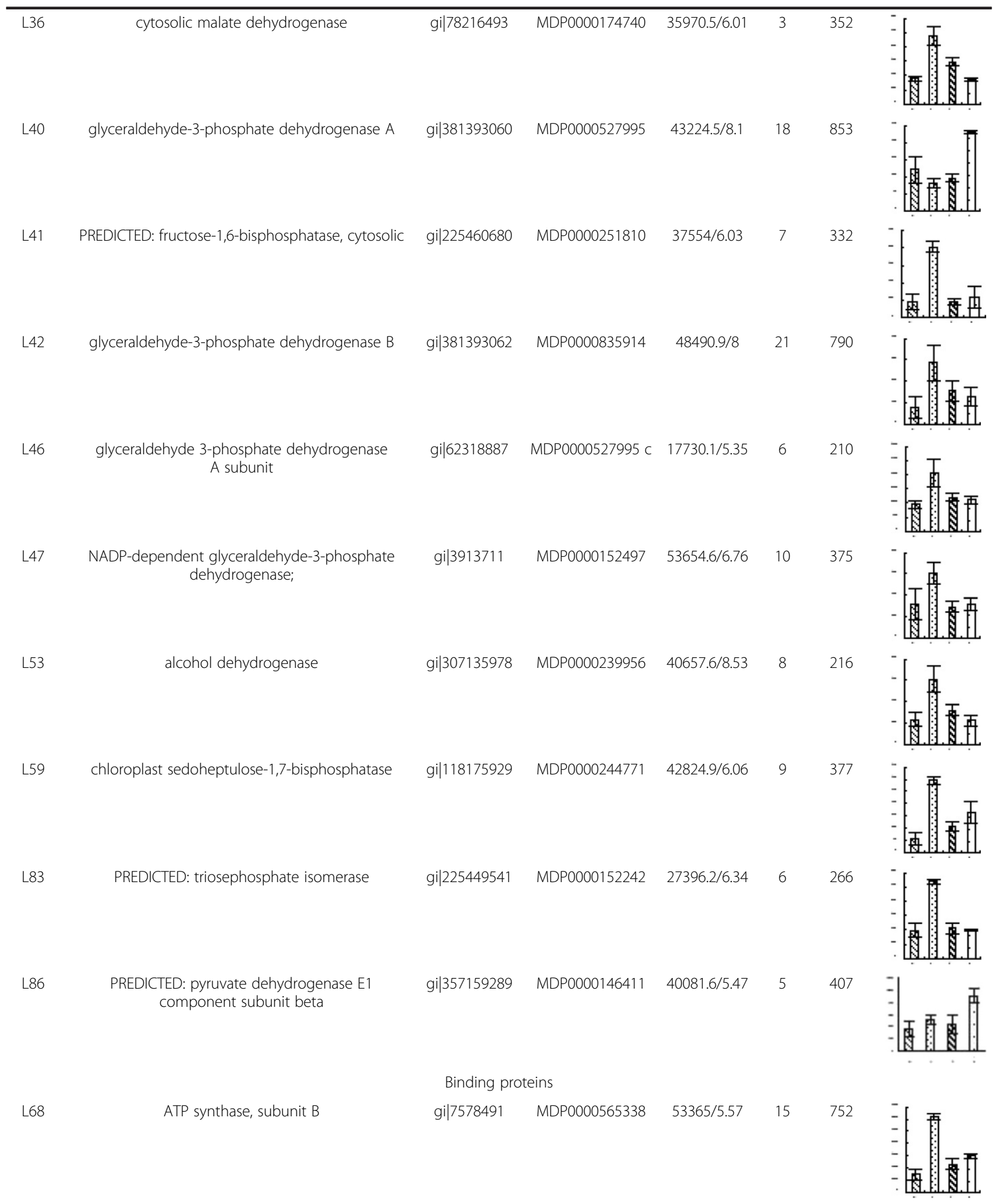




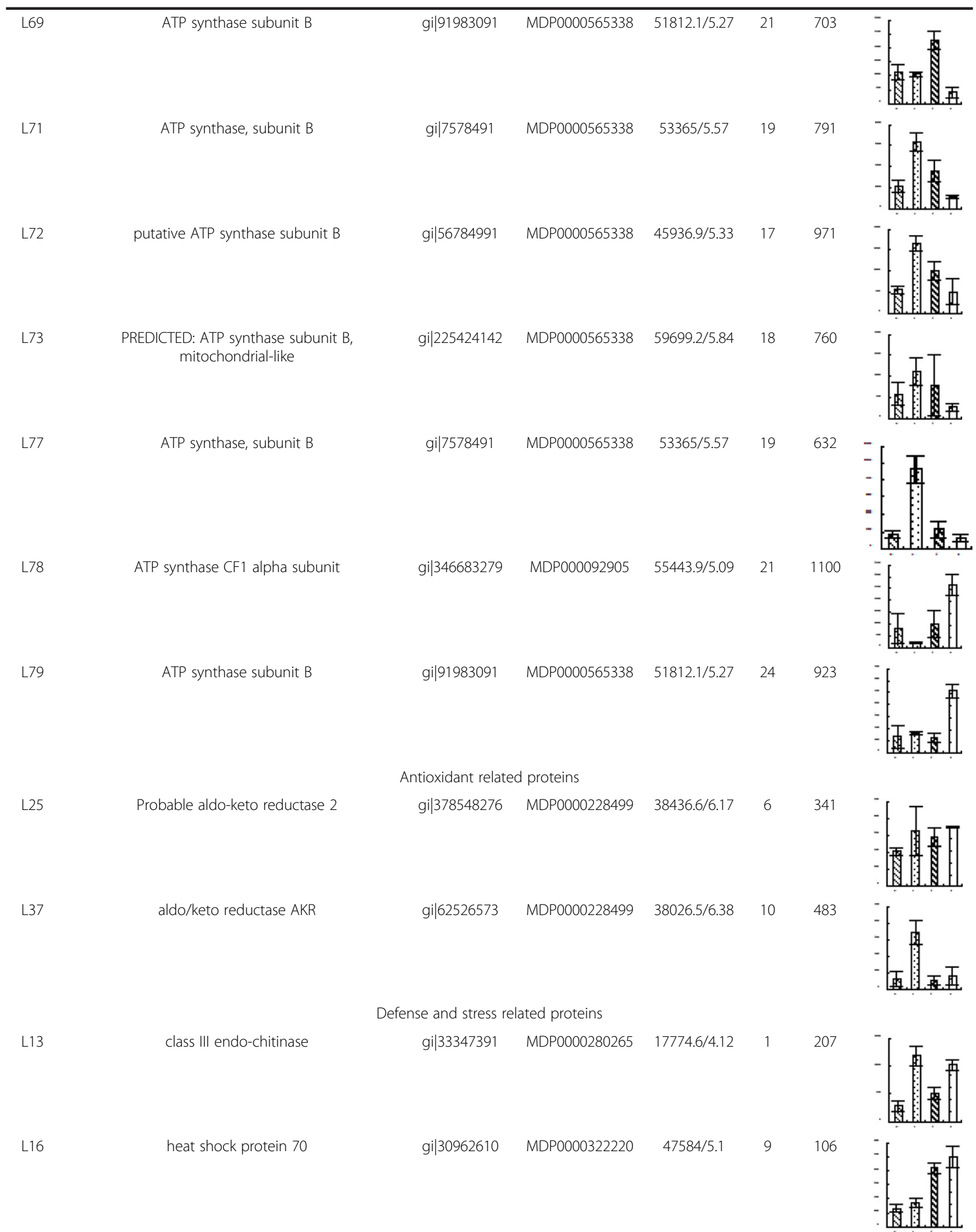


Table 1 Proteins identified and analyzed by MALDI-TOF-TOF/MS (Continued)

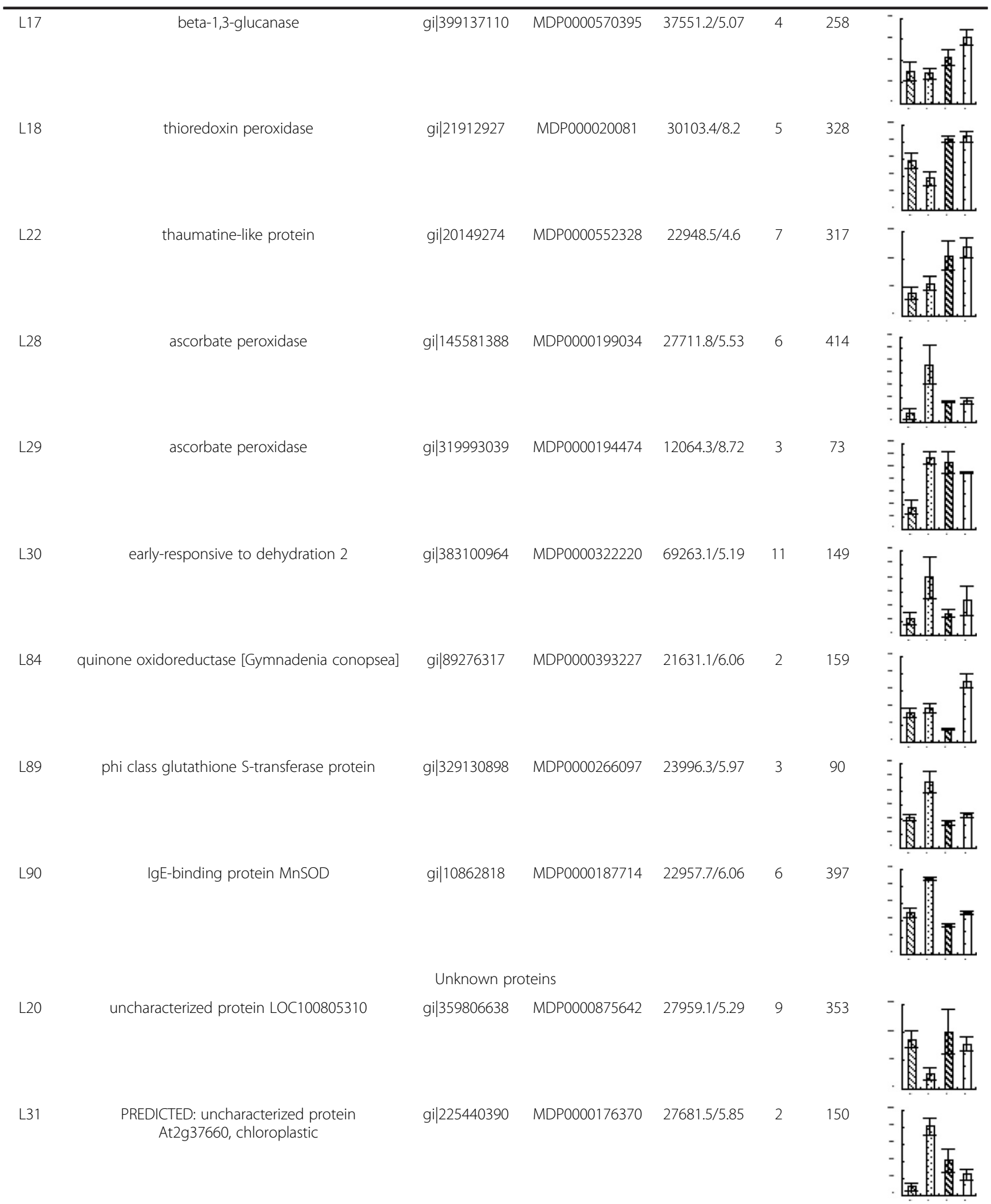


Table 1 Proteins identified and analyzed by MALDI-TOF-TOF/MS (Continued)

\begin{tabular}{|c|c|c|c|c|c|c|c|}
\hline L32 & predicted protein & gi|224087915 & MDP0000641719 & 27403.9/5.74 & 9 & 464 & $\begin{array}{l}z= \\
z \\
=\end{array}$ \\
\hline L38 & $\begin{array}{l}\text { PREDICTED: clavaminate synthase-like } \\
\text { protein At3g21360 }\end{array}$ & gi|225442460 & MDP0000406399 & $36588.7 / 6.1$ & 4 & 80 & \\
\hline L57 & predicted protein & gi|224138316 & MDP0000148186 & $45396.1 / 6.11$ & 14 & 534 & $\begin{array}{l}- \\
- \\
- \\
- \\
-\end{array}$ \\
\hline
\end{tabular}

*In relative protein content graph, from left to right were $\mathbb{N}$ : Control group 3 days post-treatment, 6 days post-treatment, $\quad$ Inoculated group, 6 days post-treatment respectively.

to inoculation (Group B); and proteins that showed increased in protein abundance in the inoculation group at both 3 day and 6 day timepoints (Group C).

The thirty-three protein spots were identified in Group A, including 8 related to photosynthesis (Rubisco, L8, L45, L49, L51, L82, L85, L95; oxygen-evolving enhancer protein 2, L50), 2 related to amino acid metabolism (L43, L54), 1 related to transport (transketolase, L56), 2 related to energy metabolism (L23, L24), eleven related to carbohydrate metabolism (L27, L33, L36, L41, L42, L46, L47, L53, L59, L83, L86), 4 related to protein binding (ATP synthase, L71, L72, L73, L77), 3 related to defense and stress response (heat shock protein 70, L16, ascorbate peroxidase, L28, L29, early-responsive to dehydration 2, L30) and 2 with unknown function (L31, L57).

Eight protein spots were identified in Group B, including 2 proteins related to photosynthesis (chlorophyll $\mathrm{a}-\mathrm{b}$ binding protein, L15, L19), 1 protein related to carbohydrate metabolism (glyceraldehyde-3-phosphate dehydrogenase A, L40), 1 protein related to protein binding (ATP synthase CF1 alpha subunit, L78), 1 protein related to antioxidant function (probable aldo-keto reductase 2, L25), 2 proteins related to defense and stress (beta-1,3glucanase, L17, quinine oxidoreductase, L84) and 1 unknown protein (L32).

There are twelve protein spots in group $\mathrm{C}$, including 2 proteins related to photosynthesis (chlorophyll a-b binding protein, L61, L87), 1 protein related to amino acid metabolism (putative plastidic glutamine synthetase, L58), 1 protein related to transport (alanine aminotransferase 3, L81), 2 proteins related to binding (ATP synthase, B subunit, L 68, L79), 1 protein related to antioxidant function (aldo/keto reductase AKR, L37), 4 proteins related to defense and stress (class III endo-chitinase, L13,

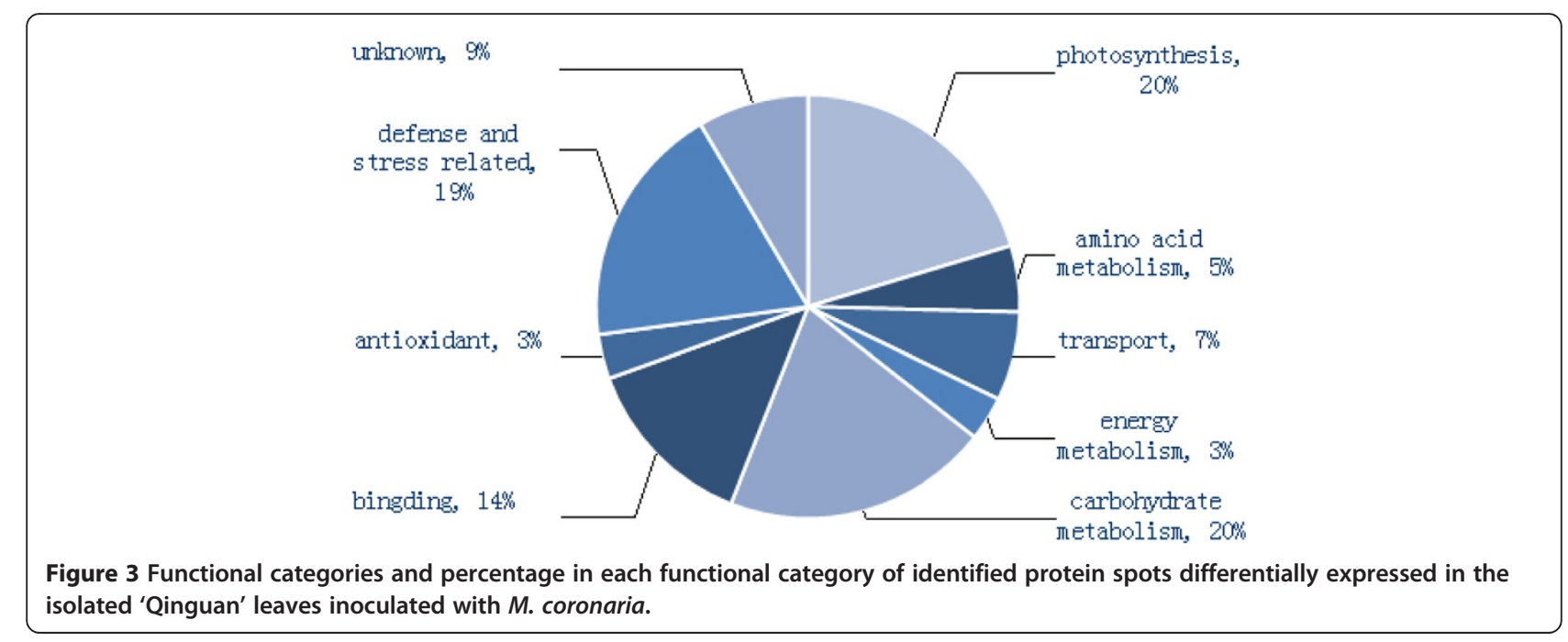




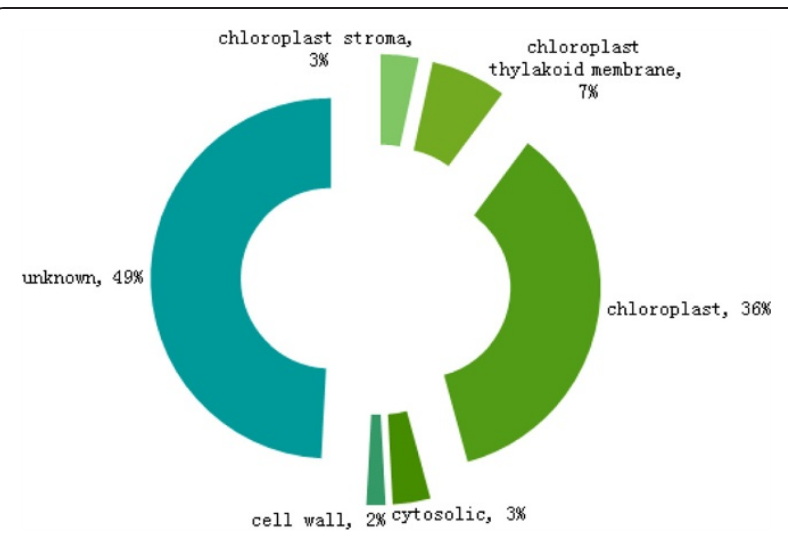

Figure 4 The subcellular location classification and percentage of protein spots differentially expressed in the isolated 'Qinguan' leaves inoculated with $M$. coronaria.

thaumatine-like protein, L22, lgE-binding protein MnSOD, L90, phi class glutathione S-transferase protein, L89), and one unknown protein (L38).

Cluster analysis of 2-D electrophoretic data of fifty-nine identified protein spots was performed with PermuMatrix (Figure 5). Among thirty-three protein spots increased in protein abundance at 3 day treatment and eight protein spots at 6 day after inoculation. These results imply that the different protein abundance can occur at a slow or fast onset in response to pathogenesis.

\section{Transcription level change of genes encoding identified proteins in response to $M$. coronaria inoculation in apple leaves}

In order to determine the relationship between the proteome data and transcriptome ones, four genes encoding identified proteins correlated with disease resistance were selected for qRT-PCR verification: class III endochitinase (L13), beta-1, 3-glucanase (L17), thaumatine-like protein (L22), and ascorbate peroxidase (L28). Primer pairs for each gene are shown in Table 2. The analysis showed that transcription levels of each gene changed over time in response to M.coronaria (Figure 6).

The transcription levels of class III endo-chitinase (L13) and beta-1, 3-glucanase (L17) are approximately consistent with the proteomics level. However, the mNA abundance of thaumatine-like protein (L22) and ascorbate peroxidase (L28) are not. The transcription levels of thaumatine-like protein (L22) had no obvious change. Ascorbate peroxidase (L28) increased the gene abundance at 3 day compared to control, but decreased at 6 day compared to control.

\section{Discussion}

To our knowledge, this is the first comparative proteomic study of apple leaf response induced by $M$. coronaria. In this study, we obtained a overview of the altered change in protein abundance in apple leaves responding to $M$. coronaria infection. We identified 59 protein spots involved in photosynthesis, amino acid metabolism, transport, energy metabolism, carbohydrate metabolism, binding, antioxidant, defense and stress. The results of the proteome analysis are discussed below and mainly focus on the groups of the defense and stress and antioxidant related proteins.

\section{Photosynthesis related proteins}

Twenty percent of the protein spots identified successfully were involved in photosynthesis. The induction of some photosynthetic proteins during the interaction between apple leaves and $M$. coronaria may implicate light-sensing mechanisms in the induction of plant disease defense signaling. A series of proteins related to photosynthesis were altered suggesting the dynamic influence of pathogen on host photosynthetic machinery $[20,21]$. Some plants show a decrease in the activity of some Calvin cycle-related proteins, e.g., RuBisCO, following pathogen infection $[22,23]$. The up-regulation of the $\mathrm{RuBisCO}$ at 3 day can be explained by the rapid defense response to the fungus. It is probable that pathogens cause a gradual decline in the rate of photosynthesis in infected areas of the plants as the disease progresses [23]. An up-accumulation of related proteins could be part of a defense strategy. At 6 day, the downregulation of protein activity indicated that infection with $M$. coronaria possible inhibited the rate and extent of photosynthetic processes. This down-regulation of photosynthesis during pathogen infection may be caused by the large accumulation of hexose sugars, which leads to feedback inhibition of the expression of some photosynthetic genes $[24,25]$. It is conform to the report by Xianping Fang et al [16].

\section{Defense and stress related proteins and antioxidant related proteins}

Twenty-two percent of the protein spots identified in this study were involved in defense and stress related and antioxidant related proteins. Plants have developed sophisticated mechanisms to protect themselves against pathogen infections. Their immunity can be triggered by pattern-recognition receptors (PRRs) that act via pathogenassociated molecular patterns (PAMP) and effectors. This recognition leads to defense responses, such as oxidative bursts, the induction of pathogenesis-related proteins, and the deposition of callose to strengthen the cell wall at sites of infection [26].

Hypersensitive Response (HR) is the most distinguishing hallmark of resistance and is characterized by rapid localized plant cell death at the site of infection $[27,28]$. The HR generates a physical barrier composed of dead 


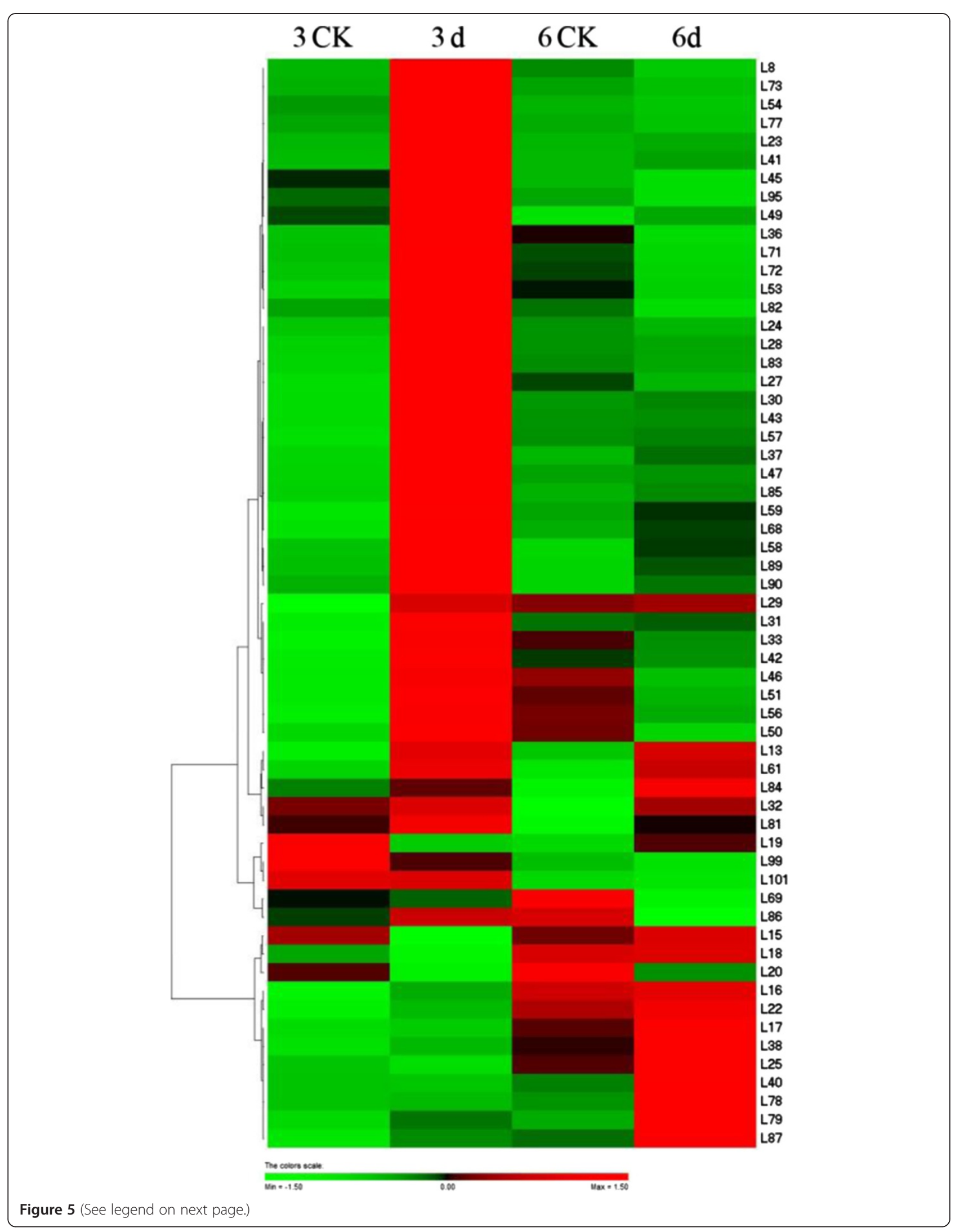


(See figure on previous page.)

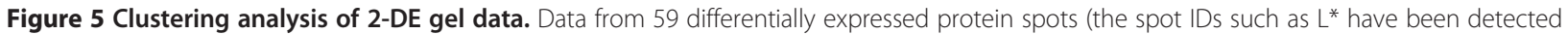
by MALDI-TOF-TOF/MS) that showed an at least 1.5-fold change in the relative volume between the inoculated and non-inoculated leaves were subjected to two-way hierarchical cluster analysis, performed with PermutMatrix. Pearson's distance and Ward's algorithm were used. Each colored cell represents the average of the relative spot volumes, according to the color scale depicted at the bottom of the figure. $3 \mathrm{CK}$-Noninoculated leaf after 3 day (treated with sterile water alone). 3d-Inoculated with M. coronaria leaf after 3 day. 6CK- Non-inoculated leaf after 6 day (treated with

sterile water alone). $6 \mathrm{~d}$-Inoculated with M. coronaria leaf after 6 day.

cells and limits the availability of nutrients to the pathogen which can further restrict its spread. Other defense related responses often accompany HR, such as oxidative burst, pathogenesis related proteins [29].

Oxidative burst, which involves the production of reactive oxygen species (ROS), is a ubiquitous response of plants to pathogen attack following successful pathogen recognition. ROS has been proposed as orchestrating the establishment of these defence responses [30]. ROSscavenging systems have an important role in regulating the amount of ROS that is generated [31]. Fungal elicitation generates a rapid oxidative burst; the host plant curtails the propagation of toxic products in order to localize the cell death [32]. In agreement with previous study, the antioxidative enzymes, for example, ascorbate peroxidase [33], quinine oxidoreductase [34], lgE-binding protein MnSOD [34], Phi class glutathione S-transferase protein [35] and aldo/keto reductase AKR, have been shown to be up-accumulated in response to $M$. coronina infection. Phi class glutathione S-transferase protein plays a key role in cellular detoxification by conjugating glutathione (GSH) to a wide variety of substrates [36]. Plant Phi class glutathione S-transferase protein can also act as a GSH peroxidase $[37,38]$. This protein can protect cells from oxygen toxicity and suppressing apoptosis [39]. These antioxidative enzymes were involved in the removal of peroxides, oxidation of toxic reductant, biosynthesis and degradation of lignin, suberization, auxin catabolism and responses to environmental stresses such as wounding, pathogenic attack and oxidative stress [40,41].

In the recent years, many aspects referred to Systemic Acquired Resistance (SAR) have been elucidated. The pathway leading to SAR involves three steps, pathogen recognition, signal relay and induction of genes, which facilitate synthesis of protective molecules. Induction of PR-1, 2, 5 and 8 is characteristic of SAR in several herbaceous plants. But very little molecular evidence for SAR in wood perennials has been reported. Jean M Bonasera et al identified four genes as candidates for involvement in the response of apple to attack by E. amylovora based on their similarity to genes documented as involved in SAR in other plants. Three of the four apple genes, PR-2, PR-5 and PR-8, but not PR-1 is up-regulated in response to inoculation with the pathogen E. amylovora. In our results, PR-2 (beta-1, 3-glucanase), PR-5 (Thaumatine-like protein) and PR-8 (Class III endo-chitinase) increased in protein abundance in response to inoculation with the pathogen $M$. coronaria, not PR-1, which conform to the result of PR gene described by Jean $M$ Bonasera et al and Van Loon et al. [42,43].

Chitinase gene and beta-1, 3-glucanses gene were demonstrated to be multigene family among apple species. Different members in the gene family existed expression difference by inoculation induction. The induced expression of class III endo-chitinase (L13, gi|33347391, MDP0000280265) and beta-1, 3-glucanses (L 17, gi| 399137110,MDP0000570395) were shown in this study.

It was previously possible to detect the proteins chitinase and beta-1, 3-glucanses in the apoplast fluid of the M. domestica [44]. Chitinase and beta-1, 3-glucanase could protect plants against fungal infection in two ways. First, these proteins can directly weaken and decompose the fungal cell walls [45]. Second, oligosaccharide elicitors, released through those digested walls, can induce a

Table 2 Gene-specific primer pairs used for qRT-PCR analysis of four identified genes in 'Qinguan' leaves inoculated with $M$. coronaria

\begin{tabular}{|c|c|c|c|}
\hline Spot no. & Gene name & Accession no. & Primer sequence $\left(5^{\prime}-3^{\prime}\right)$ \\
\hline \multirow[t]{2}{*}{ L13 } & Class III endo-chitinase & gi|33347391 & Forward: GCACTCAACGGACACAAC \\
\hline & & & Reverse: GTAGAACTGAACCCAAACG \\
\hline \multirow[t]{2}{*}{ L17 } & Beta-1, 3-glucanase & gi|399137110 & Forward: AGTCGTATCGGAGAGTGGTTG \\
\hline & & & Reverse: TGAGTTGGTACTTGGGTTGTTT \\
\hline \multirow[t]{2}{*}{ L22 } & Thaumatine-like protein & gi|20149274 & Forward: ATGGTCTGGTCGCTTCTG \\
\hline & & & Reverse: CCGTCAACAAGGCTAACA \\
\hline \multirow[t]{2}{*}{ L28 } & Ascorbate peroxidase & gi|145581388 & Forward: AAGGTGCCACAAGGAGCG \\
\hline & & & Reverse: AGAGGGCGGAAGACAGGG \\
\hline
\end{tabular}




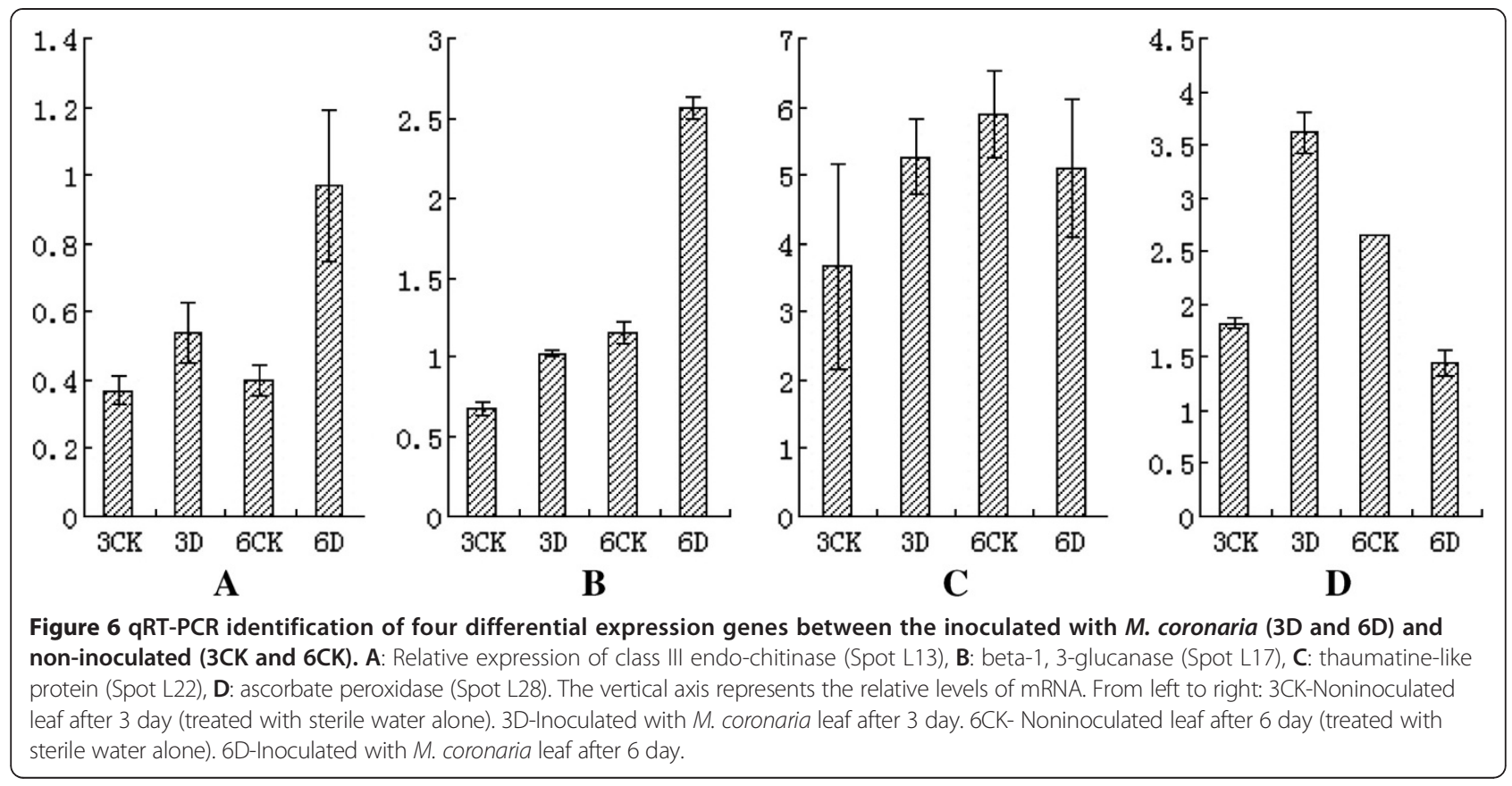

consequent chain of defense reactions [46]. Activities by chitinase and beta-1, 3-glucanase can be significantly induced by infection, as shown in several pathosystems [47,48]. Additionally, the activities of those are higher during an incompatible interaction than in one that is compatible [49]. Thaumatine-like protein (L22), a class 5-PR protein (PR-5), has previously exhibited a number of anti-fungal properties [50]. Moreover, the transgenic expression of thaumatine-like protein engendered antifungal activity through the inhibition of mycelial growth [51,52]. These proteins identified in this work were generally consistent with previous studies on the transcriptional and proteomics response of disease. In agreement with the work of Venisse et al. Chitinase and beta-1, 3 glucanase were up-regulated in response to E. amylovora challenge [53]. In agreement with the work of Xianping Fang et al. [16], beta-1, 3-glucanase was up-regulated in response to $C$. fragariae of strawberry leaves.

The constitutive expression of the PR proteins, especially in the apoplast of the M.domestic, and possibly also in other parts of the leaf, is most probably responsible for strengthening the cell wall, as well as for rapid degradation of $M$. coronaria mycelium and for the failure of the fungus to complete its life cycle in the apoplast. It is well documented in the literature that plant defence against pathogens involves an oxidative burst and that the reactive oxygen species not only damage the pathogen but also the plant itself [54].

\section{The other proteins}

In plants, pathogenic infections often induce some common physiological alterations, for example amino acid, energy and carbohydrate metabolism, transport, binding and et al. In our study, enzymes involved these functions were found to be differentially regulated in response to $M$. coronaria infection. Ferredoxin-NADP reductase (L23) is a key enzyme of electrons. Ferredoxin-NADP reductase transfers electrons between the one-electron carrier ferredoxin and the two-electron carrier NADP $(\mathrm{H})$ at the end of the electron transport chain. This reaction provides the NADPH necessary for $\mathrm{CO} 2$ assimilation in plants. Ferredoxin-NADP reductase also participates in other relevant processes as the electron cyclic flow around the photosystem I and in the control of the NADPH/ NADP + homeostasis of stressed chloroplasts [55]. After SCMV infection, ferredoxin-NADP reducase was upaccumulated at 3 day, while recovered at 6 day. The result indicates that the ability of energy metabolism might increase at 3 day, however recovered at 6 day. Glyceraldehyde-3-phosphate dehydrogenase (L42), the key enzyme of carbohydrate metabolism, increased in protein abundance. The expression patterns consistent with those reported previously [56]. We speculated that $M$. coronaria infection might result in the signal recognition particle (SRP) to synthesize more glucose, fructose and betaine. The synthesis of these energy substances can maintain intracellular homeostasis.

\section{Unknown proteins}

In addition to the positively identified proteins in this study, a number of differentially expressed proteins could not be associated with an existing biological function. These candidate proteins will require further study in the future. 


\section{Correlation between pathogenically induced gene} transcription level abundance and protein abundance In order to determine the correlation between levels of protein abundance and their corresponding mRNA level, the relative abundance of four genes including class III endo-chitinase (L13), beta-1, 3-glucanase (L17), thaumatine-like protein (L22), and ascorbate peroxidase (L28) was assessed at 3 and 6 days post-inoculation. Hierarchical clustering was also performed to achieve a more intuitive overview of the correlation between pathogen induced gene abundance and protein abundance (Figure 7). Variation in mRNA levels of class III endo-chitinase (L13) and beta-1, 3-glucanase (L17) exhibited a good relation with the proteomic level. Transcription levels of thaumatine-like protein (L22) had no obvious difference. Conversely, mRNA abundance of ascorbate peroxidase (L28) was only increased at 3 day post-inoculatio and decrease at 6 day. Despite the fact that protein abundance has no change at 6 day. The inconsistency between transcription and translation level does not account for their independence, and perhaps their major roles are regulatory effects including transcriptiona regulation, differential processing of RNA transcript and differential translation of mRNA [57]. The inconsistency between transcriptional and translational levels is influenced by many factors, and thus the further verification is required to elucidate its mechanisms.

\section{Conclusion}

In a conclusion, different proteins in response to Marssonina coronaria were identified by proteomic analysis. Among of these proteins, there are some PR proteins, for example class III endo-chitinase, beta-1,3 glucanase and thaumatine-like protein, and some antioxidant related proteins including aldo/keto reductase AKR, ascorbate peroxidase and phi class glutathione S-transferase protein that were associated with disease resistance. The transcription levels of class III endo-chitinase (L13) and

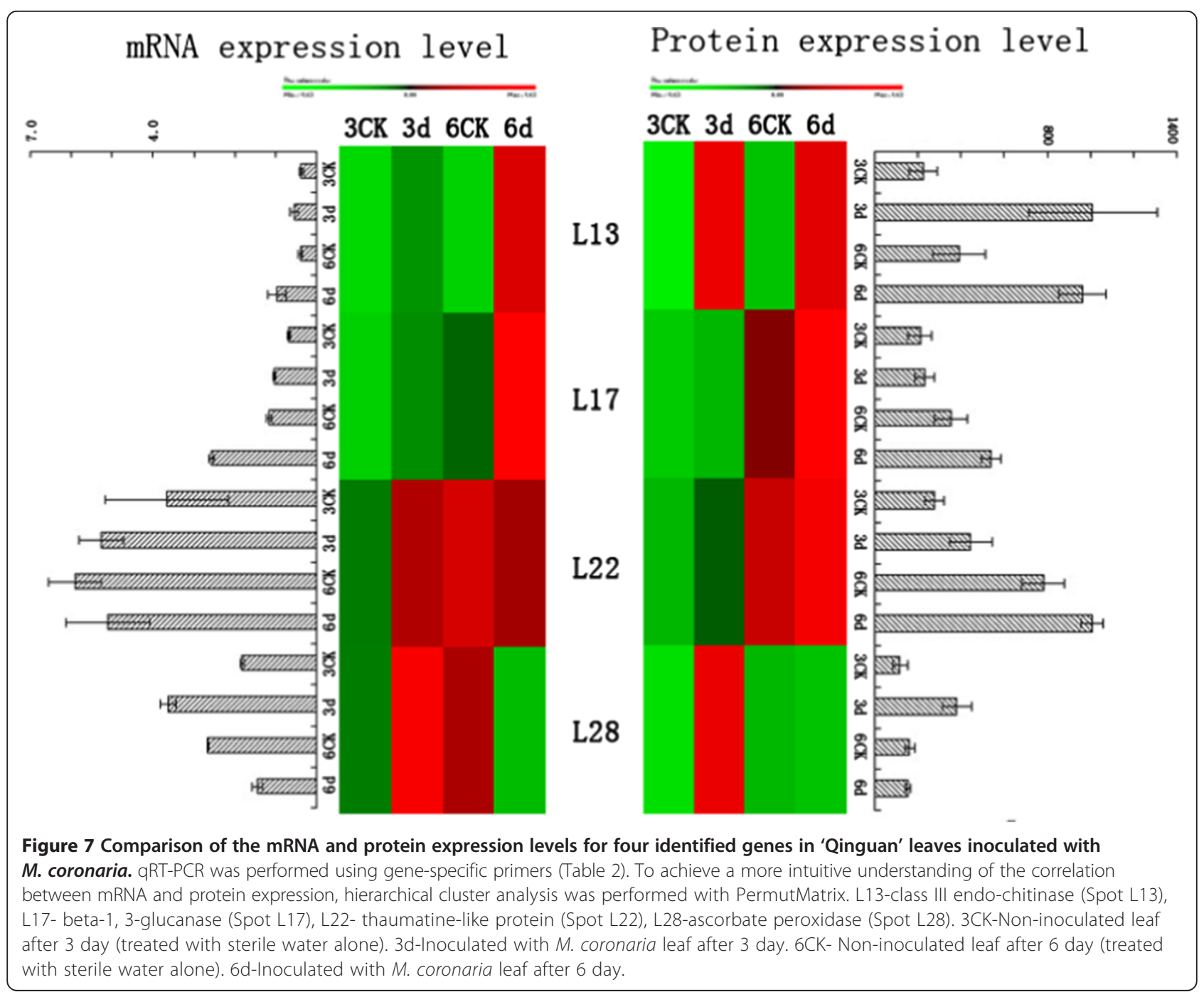


beta-1, 3-glucanase (L17) have a good relation with the data of the proteomics level, however, the mRNA abundance of thaumatine-like protein (L22) and ascorbate peroxidase (L28) are not. To elucidate the resistant mechanism, the data in the present study will promote us to investigate further the expression regulation of these target proteins.

\section{Methods}

\section{Plant material and $M$. coronaria inoculation}

Uniform and healthy mature 'Qinguan' apple leaves were obtained from apple repository of Northwest A \& F University. After harvest, the leaves were immediately surface-sterilized with $8 \%$ sodium hypochlorite for $10 \mathrm{~min}$. The petiole was rinsed with sterile water, air-dried, and wrapped with sterile cotton. Treatment with sterile water was used as a control versus $M$. coronaria inoculation, performed by pipetting 20 conidial suspension spots $\left(10^{6}\right.$ conidia $\mathrm{ml}^{-1}, 20 \mu \mathrm{l}$ per infection spot) on the upper leaf surface. The leaves were cultured in an incubator at $25^{\circ} \mathrm{C}$ with a relative humidity of $95-100 \%$. Leaves from treatment and control were collected at 3 and 6 days post-inoculation, immediately frozen in liquid nitrogen and stored at $-70^{\circ} \mathrm{C}$ until further use.

A monosperse culture of Marssonina blotch-derived Diplocarpon mail was collected from Northwest A \& F University. Single spore isolation was performed according to procedures outlined by Lee et al. [6].

\section{Total protein extraction and 2-D gel electrophoresis of apple leaves}

Three independent replicates of each apple leaf sample were crushed in a pre-cooled mortar with liquid nitrogen until a fine powder was formed. Total protein content was extracted with TCA-phenol, as described previously [58]. Precipitated protein was re-suspended in sample buffer containing $7 \mathrm{M}$ Urea (Merck), $2 \mathrm{M}$ Thiourea (Sigma Aldrich), 2\% (w/v) CHAPS (Sigma Aldrich), 2\% (v/v) DTT (Sigma Aldrich) and Bromophenol blue traces (Sigma Aldrich). Protein concentration was determined via Bradford assay (BioRad), diluted to a final concentration of $3 \mathrm{ug} / \mathrm{ul}$, and stored at $-20^{\circ} \mathrm{C}$.

Protein samples (total $1000 \mathrm{ug}, 350 \mathrm{ul}$ ) were loaded onto $17 \mathrm{~cm} \mathrm{pH} \mathrm{4-7} \mathrm{IPG} \mathrm{strips} \mathrm{with} \mathrm{active} \mathrm{rehydration}$ loading buffer for 1 hour in sample buffer (described previously) with the addition of $0.2 \%(\mathrm{v} / \mathrm{v})$ IPG buffer (pH 4-7). Isoelectric focusing (IEF) was performed on a Bio-Rad IEF system at $25^{\circ} \mathrm{C}$ using the following protocol: S1 linear 250 V 30 min, S2 rapid 500 V 30 min, S3 rapid $1000 \mathrm{~V} 1 \mathrm{~h}, \mathrm{~S} 4$ linear 10,000 V 4 h, S5 rapid 10,000 V 60 kVh, S6 rapid 500 V $24 \mathrm{~h}$. Subsequently the IPG strips were equilibrated by gentle shaking for $15 \mathrm{~min}$ in equilibration buffer I [6 M urea, 2\% (w/v) SDS, $0.374 \mathrm{M}$ Tris$\mathrm{HCl}(\mathrm{pH}$ 8.8), 20\% (w/v) glycerol, 2\% (w/v) DTT] followed by $15 \mathrm{~min}$ in equilibration buffer II (2.5\% iodoacetamide instead of DTT). Each strip was then transferred onto vertical slab $12 \%$ SDS-polyacrylamide gels. Electrophoresis was run at $15^{\circ} \mathrm{C}$ for $30 \mathrm{~min}$ at $80 \mathrm{~V}$ followed by $100 \mathrm{~V}$ for $10 \mathrm{~h}$. The gels were stained with colloidal Coomassie Brilliant Blue G-250 [59], washed three times with Milli-Q water for 5 mins and fastened in fixative solution $[40 \%(\mathrm{v} / \mathrm{v})$ ethanol, $10 \%(\mathrm{v} / \mathrm{v})$ acetic acid and $10 \%(\mathrm{v} / \mathrm{v})$ carbinol] for $1 \mathrm{~h}$. After a second set of Milli-Q water washes, the gel was stained with colloidal Coomassie Brilliant Blue [0.1\% (w/v) CBB G-250, $10 \%(\mathrm{w} / \mathrm{v})$ ammonium sulfate, $1.2 \%(\mathrm{v} / \mathrm{v})$ phosphoric acid and $20 \%(\mathrm{v} / \mathrm{v})$ ethanol] overnight. Finally, background staining was removed with destaining solution $[10 \%(\mathrm{v} / \mathrm{v})$ ethanol, 10\% (v/v) acetic acid].

\section{Gel image acquisition and cluster analysis}

Gel images were acquired using a Powerlook2100XL optical density scanner and imported into PDQuest 8.0.1 image software (Bio-Rad, Hercules CA, USA) for analysis. A total of 36 gels, resulting from three technical replicates for each biological replicate, were analyzed. A 1.5 -fold change in protein expression between inoculated and control states was deemed to be statistically significant. PermutMatrix was used to conduct cluster analysis for different treatments, with parameters set as following: Dissimilarity: Pearson's distance, Hierarchical: Ward's Minimmu Variance Method, Used dataset: Normalize Rows (z-score). After analysis by PDQuest image software, differential protein spots were excised from the preparative gels and stored in $2 \mathrm{ml}$ Eppendorf tubes.

\section{Protein identification by MALDI-TOF-TOF/MS Analysis}

Gel fragments were destained with $300 \mu \mathrm{l} 100 \mathrm{mM}$ $\mathrm{NH}_{4} \mathrm{HCO}_{3}$ and $30 \%$ acrylonitrile (ACN). After removed the destaining buffer using $100 \% \mathrm{ACN}$, the gel pieces were lyophilized. The dry gel fragments were rehydrated in $5 \mu \mathrm{l} \mathrm{2.5-10} \mathrm{ng} / \mu \mathrm{l}$ trypsin (Promega, Madison, WI, USA) for approximately $20 \mathrm{~h}$. After removal of hydrolysate, the remaining peptides were extracted in $100 \mu \mathrm{l} 60 \%$ $\mathrm{ACN}$ by sonication. Extracts were pooled together and lyophilized. The resulting lyophilized tryptic peptides were kept for mass spectrometric analysis.

MS spectrum analysis was performed with a 4800 Plus MALDI TOF/TOF ${ }^{\text {mi }}$ Analyzer (Applied Biosystems, USA). Analysis was completed on behalf of The Biochemistry and Cell Biology Shanghai Institute for Biological Sciences, Chinese Academy of Sciences.

\section{Database search and protein identification}

MS spectral data obtained was analyzed using GPS Explore software, and the results of each sample were integrated into one file. The results were searched against the NCBI nr database using MASCOT software (Matrix 
Science, London, U.K.). Protein content was determined using PD-Quest software.

\section{Total RNA isolation and Quantitative Real Time-PCR}

Total RNA was isolated from inoculated and control leaves by the CTAB method described by Ksenija et al with modifications [60]. RNase-free DNase I (TaKaRa, Dalian, China) was used to eliminate genomic DNA according to the manufacturer's instructions. The integrity of RNA was checked by electrophoresis using a 1\% agarose gel. RNA was reverse-transcribed using the PrimeScript RT reagent Kit With gDNA Eraser (TaKaRa, Dalian, China) according to manufacturer instructions.

Protein candidates highly correlated with disease resistance were selected for qRT-PCR examination. The $M$. domestica housekeeping gene actin-2 was used as an endogenous reference for relative quantification. The following actin-2 primers were used: forward primer $5^{4}$ CGATGGCCAAGTCATCACAAT-3', reverse primer 5'GACCCACCACTGAGCACGATG-3' [61]. The qRT-PCR was set to cycling parameters of $95^{\circ} \mathrm{C}$ for 2 min followed by 40 cycles of $95^{\circ} \mathrm{C}$ for $30 \mathrm{~s}, 58^{\circ} \mathrm{C}$ for $30 \mathrm{~s}$, and $72^{\circ} \mathrm{C}$ for 30s.

\section{Competing interests}

The authors declare that they have no competing interests and declare no conflict of interest.

\section{Authors' contributions}

MML: participated on study design and all experimental procedures as well as the manuscript draft. JHX and JZ: participated on experimental procedures. ZHQ: participated on experiment execution. JKZ: performed the study design and coordinated the manuscript draft. All authors read and approved the final manuscript.

\section{Acknowledgments}

The authors are grateful to Professor Pengmin Li for help in revising the manuscript. This research was supported by the earmarked fund for the China Agriculture Research System (CARS-28).

\section{Author details}

${ }^{1}$ College of Horticulture, Northwest A \& F University, Yangling, Shaanxi 712100, China. ${ }^{2}$ State Key Laboratory of Crop Stress Biology in Arid Areas, Northwest A \& F University, Yangling, Shaanxi 712100, China.

Received: 15 August 2013 Accepted: 27 January 2014

Published: 7 February 2014

\section{References}

1. Newcomb RD, Crowhurst RN: Analyses of expressed sequence tags from apple. Plant Physiol 2006, 141:147-166.

2. Sharma JN, Sharma A, Sharma P: Out-break of Marssonina blotch in warmer climates causing premature leaf fall problem of apple and its management. Acta Hortic 2004, 662:405-409.

3. Sangong DH, Kweon HJ, Song YY: Influence of defoliation by Marssonina blotch on vegetative growth and fruit quality in 'Fuji'/M.9 apple tree, in Korean. J Hortic Sci \& Tech 2011, 29:531-538.

4. Yin L, Wang P, Li M: Exogenous melatonin improves Malus resistance to Marssonina apple blotch. J Pineal Res 2013, 54:426-434.

5. Zhao H, Zhou TC, Cheng JJ: Control effect of triazole fungicides in controlling Marssonina coronaria in vitro and in field. Sci Sinica 2009, 45:68-73.
6. Lee DH, Back CG, Win NKK: Biological characterization of Marssonina coronaria associated with apple blotch disease. Mycobiology 2011, 39:200-205.

7. Zhao H, Han Q, Wang J: Cytology of infection of apple leaves by Diplocarpon mali. Eur J Plant Pathol 2013, 136:41-49.

8. Yin L, Li M, Ke X: Evaluation of Malus germplasm resistance to Marssonina apple blotch. Eur J Plant Pathol 2013, 136:597-602.

9. Zhou Q, Gao H, Wang M: Characterization of defense-related genes in the 'Qinguan' apple in response to Marssonina coronaria. S Afr J of Bot 2012, 80:36-43.

10. Agrawal GK, Yonekura M, Iwahashi Y: System, trends and perspectives of proteomics in dicot plants: Part III: unraveling the proteomes influenced by the environment, and at the levels of function and genetic relationships. J Chromatogr B 2005, 815:137-145.

11. Butt YKC, LO SCL: Proteomic studies on plant-pathogen interaction in compatible and incompatible systems. Proteomics 2007, 4:141-156.

12. Tahara ST, Mehta A, Rosato YB: Proteins induced by Xanthomonas axonopodis pv. passiflorae with leaf extract of the host plant (Passiflorae edulis). Proteomics 2003, 3:95-102.

13. Metha A, Rosato YB: Differentially expressed proteins in the interaction of Xanthomonas axonopodis pv. citri with leaf extract of the host plant. Proteomics 2001, 1:1111-1118.

14. Mathesius U: Comparative proteomic studies of root-microbe interactions. J Proteomics 2009, 72:353-366.

15. Fang $X, M a H, L u D$ : Comparative proteomics analysis of proteins expressed in the $\mathrm{I}-1$ and $\mathrm{I}-2$ internodes of strawberry stolons. Proteome SCi 2011, 9:26.

16. Fang $X$, Chen $W, X$ in $Y$ : Proteomic analysis of strawberry leaves infected with Colletotrichum fragaria. J Proteomics 2012, 75:4074-4090.

17. Cocco L, Manzoli L, Barnabei AM: Significance of subnuclear localization of key players of inositol lipid cycle. Adv Enzyme Regul 2004, 44:51-60.

18. Chou KC, Cai YD: Prediction of protein subcellular locations by GO-FunDPseAA predictor. Biochem Biophys Res Commun 2004, 320:1236-1239.

19. Lei ZZ, Dai Y: Assessing protein similarity with gene ontology and its use in subnuclear localization prediction. BMC Bioinformatics 2006, 7:491.

20. Rolland F, Moore B, Sheen J: Sugar sensing and signaling in plants. Plant Cell 2002, 25:S185-S205.

21. Berger S, Sinha AK, Roitsch T: Plant physiology meets phytopathology: plant primary metabolism and plant-pathogen interactions. J Exp Bot 2007, 58:4019-4026.

22. Gordon TR, Duniway JM: Effects of powdery mildew infection on the efficiency of $\mathrm{CO} 2$ fixation and light utilization by sugar beet leaves. Plant Physiol 1982, 69:139-142.

23. Walters DR, Ayres PG: Ribulose bisphosphate carboxylase protein and enzymes of $\mathrm{CO} 2$ assimilation in barley infected by powdery mildew (Erysiphe graminis hordei). J Phytopathology 1984, 109:208-218.

24. Swarbrick PJ, Schulze-Lefert P, Scholes JD: Metabolic consequences of susceptibility and resistance (race-specific and broad-spectrum) in barley leaves challenged with powdery mildew. Plant, Eell \& Environment 2006, 29:1061-1076.

25. Fotopoulos V, Gilbert MJ, Pittman JK: The monosaccharide transporter gene, AtSTP4, and the cell-wall invertase, Atbfruct1, are induced in Arabidopsis during infection. Plant Physiol 2003, 132:821-829.

26. Chisholm ST, Coaker G, Day B: Host-microbe interactions: shaping the evolution of the plant immune response. Cell 2006, 124:803-814.

27. Dangl JL, Dietrich RA, Richeiberg MH: Death don't have no mercy: cell death programs in plant-microbe interactions. Plant Cell 1996, 8:1793-1807.

28. Lamb C, Dixon RA: The oxidative burst in plant disease resistance. Annu Rev Plant Physiol and Plant Mol Biol 1997, 48:251-275.

29. Baldo A, Norelli JL, Farrell RE: Identification of genes differentially expressed during interaction of resistant and susceptible apple cultivars (Malus $\times$ domestica) with Erwinia amylovora. BMC plant biology 2010, 10:1

30. Levine $\mathrm{A}$, Tenhaken $\mathrm{R}$, Dixon $\mathrm{R}: \mathrm{H} 2 \mathrm{O} 2$ from the oxidative burst orchestrates the plant hypersensitive disease resistance response. Cell 1994, 79:583-593.

31. Torres MA, Jones JDG, Dangl JL: Reactive oxygen species signaling in response to pathogens. Plant Physiol 2006, 141:373-378.

32. Chivasa S, Hamilton JM, Pringle RS, Ndimba BK, Simson WJ, Lindsey K: Proteomic analysis of differentially expressed proteins in fungal elicitortreated Arabidopsis cell cultures. J Exp Bot 2006, 57:1553-1562. 
33. Wu L, Han Z, Wang S: Comparative proteomic analysis of the plant-virus interaction in resistant and susceptible ecotypes of maize infected with sugarcane mosaic virus. J Proteomics 2013, 89:124-140.

34. Barilli E, Rubiales D, Castillejo MÁ: Comparative proteomic analysis of BTH and BABA-induced resistance in pea (Pisum sativum) toward infection with pea rust (Uromyces pisi). J Proteomics 2012, 75:5189-5205.

35. Fung RWM, Gonzalo M, Fekete C: Powdery mildew induces defenseoriented reprogramming of the transcriptome in a susceptible but not in a resistant grapevine. Plant Physiol 2008, 146:236-249.

36. Hayes JD, Flanagan JU, Jowsey IR: Glutathione transferases. Annu R Pharmacol Toxicol 2005, 45:51-88.

37. Bartling D, Radzio R, Steiner U, Weiler EW: A glutathione S-transferase with glutahion-peroxidase activity from Arabidopsis thaliana, Molecular cloning and functional characterization. Eur JBiochem 1993, 216:579-586.

38. Cummins I, Cole DJ, Edwards R: A role for glutathione transferases functioning as glutathione peroxidases in resistance to multiple herbicides in blackgrass. Plant J 1999, 18:285-292

39. Ryu HY, Kim SY, Park HM: Modulations of AtGSTF10 expression induce stress tolerance and BAK1-mediated cell death. Biochem Bioph R Commun 2009, 379:417-422.

40. Hilaire E, Young SA, Willard LH: Vascular defense responses in rice: peroxidase accumulation in xylem parenchyma cells and xylem wall thickening. Mol Plant Microbe Interactions 2001, 14:1411-1419.

41. Kawaoka A, Matsunaga E, Endo S, Kondo S: Ectopic expression of a horseradish peroxidase enhances growth rate and increases oxidative stress resistance in hybrid aspen. Plant Physiol 2003, 132:1177-1185.

42. Bonasera JM, Kim JF, Beer SV: PR genes of apple: identification and expression in response to elicitors and inoculation with Erwinia amylovora. BMC Plant Biol 2006, 6:23.

43. Van Loon LC, Pierpoint WS, Boller TH: Recommendations for naming plant pathogenesis-related proteins. Plant Mol Biol Rep 1994, 12:245-264.

44. Degenhardt J, Al-Masri AN, Kürkcüoglu S: Characterization by suppression subtractive hybridization of transcripts that are differentially expressed in leaves of apple scab-resistant and susceptible cultivars of Malus domestica. Mol Genet Genomics 2005, 273:326-335.

45. Mauch F, Mauch-Mani B, Boller T: Antifungal hydrolases in pea tissue II. Inhibition of fungal growth by combinations of chitinase and b-1,3glucanase. Plant Physiol 1988, 88:936-942

46. Lawerance CB, Singh NP, Qiu J: Constitutive hydrolytic enzymes are associated with polygenic resistance of tomato to Alternaria solani and may function as an elicitor release mechanism. Physiol Mol Plant P 2000, 57:211-220.

47. Boller T, Gehri A, Mauch F: Chitinase in bean leaves: induction by ethylene, purification, properties, and possible function. Planta 1983, 157:22-31.

48. Ryals J, Uknes S, Ward E: Systemic acquired resistance. Plant Physiol 1994, 104:1109-1112.

49. Liu B, Xue X, Cui S: Cloning and characterization of a wheat b-1,3-glucanase gene induced by the stripe rust pathogen Puccinia striiformis $f$. sp. tritici. Mol Biol Rep 2010, 37:1045-1052.

50. Van Loon LC, Rep M, Pieterse CMJ: Significance of inducible defenserelated proteins in infected plants. Annu Rev Phytopathol 2006, 44:135-162.

51. Ho VSM, Wong JH, Ng TB: A thaumatin-like antifungal protein from the emperor banana. Peptides 2007, 28:760-766.

52. Kim BG, Fukumoto T, Tatano S, Gomi K, Ohtani K, Tada Y: Molecular cloning and characterization of a thaumatin-like protein-encoding CDNA from rough lemon. Physio Mol Plant P 2009, 74:3-10.

53. Venisse J-S, Malnoy M, Faize M, Paulin JP, Brisset MN: Modulation of defense responses of Malus spp. during compatible and incompatible interactions with Erwinia amylovora. Mol Plant Microb Interact 2002, 15:1204-1212

54. Apel K, Hirt H: Reactive oxygen species: metabolism, oxidative stress, and signal transduction. Annu Rev Plant Biol 2004, 55:373-399.

55. Palatnik JF, Valle EM, Carrillo N: Oxidative stress causes ferredoxin-NADP + reductase solubilization from the thylakoid membranes in methylviologen-treated plants. Plant Physiol 1997, 115:1721-1727.

56. Wang $H$, Yang $Y$, Chen W: Identification of differentially expressed proteins of Arthrospira (Spirulina) plantensis-YZ under salt-stress conditions by proteomics and qRT-PCR analysis. Proteome sci 2013, 11:6.
57. Matsuda N, Uozumi N: Ktr-mediated potassium transport, a major pathway for potassium uptake, is coupled to a proton gradient across the membrane in Synechocystis sp. PCC 6803. Biosci Biotech Biochem 2006, 70:273-275.

58. Wang W, Vignani $R$, Scali M: A universal and rapid protocol for protein extraction from recalcitrant plant tissues for proteomic analysis. Electrophoresis 2006, 27:2782-2786.

59. Candiano G, Bruschi M, Musante L: Blue silver: a very sensitive colloidal Coomassie G-250 staining for proteome analysis. Electrophoresis 2004, 25:1327-1333.

60. Ksenija G, Alvaro H, Schuyler SK: RNA extraction from different apple tissues rich in polyphenols and polysaccharides for cDNA library construction. Plant Mol Biol Rep 2004, 22:437-438.

61. Choi YO, Kim SS, Lee S, Kim S: Isolation and promoter analysis of antherspecific genes encoding putative arabinogalactan proteins in Malus $X$ domestica. Plant Cell Report 2010, 29:14-24.

doi:10.1186/1477-5956-12-7

Cite this article as: Li et al:: Screening and identification of resistance related proteins from apple leaves inoculated with Marssonina coronaria (Ell. \& J. J. Davis). Proteome Science 2014 12:7

\section{Submit your next manuscript to BioMed Central and take full advantage of:}

- Convenient online submission

- Thorough peer review

- No space constraints or color figure charges

- Immediate publication on acceptance

- Inclusion in PubMed, CAS, Scopus and Google Scholar

- Research which is freely available for redistribution 